\title{
Welcome to Translational Breast Cancer Research
}

The field of breast cancer research has brought together countless remarkably talented and dedicated scientists and clinicians in recent years. The diagnosis and treatment of breast cancer in China has been continuously optimized through the efficient and hard work of these professionals, and the impact of Chinese breast cancer research in the global arena has been elevated. Thus, a journal that embodies both national insight and international perspective is urgently needed.

In July 2019, after thorough discussion, we initiated the publication of this new journal: "Translational Breast Cancer Research" (TBCR). In April 2020, TBCR is officially launched to our readers. Notably, in February 2020, the Chinese Ministry of Science and Technology called for the publication of high-quality articles, including these published in Chinese journals with international impact, these published in well-recognized international top or key scientific journals, and these in the proceedings of domestic and foreign top academic conferences. This reaffirmed our determination to launch TBCR, and to steer it towards becoming a potentially influential publication on a worldwide scale.

Our goal is to provide a professional platform for learning and communication. As an open-access, peer-reviewed international journal, TBCR is committed on highlighting the latest advances in breast cancer research and providing practical diagnostic information, expert opinions, consensuses and controversies. This journal will cover topics including the diagnosis and treatment of breast cancer, translational medicine, the use of big data and artificial intelligence in a clinical context. They will be presented in the form of original articles, reviews, commentaries, consensuses/guidelines, and case reports. Peer reviewers will be invited to assess the quality of each article. To ensure all submissions are reviewed effectively, numerous scholars of excellence from across the globe have been invited to join the editorial board. These reviewers are not specifically confined to breast cancer oncologists but also include experts in statistics, epidemiology, and basic medicine.

Lastly, we would like to thank our peers across the globe whose assistance and support made this journal possible. In addition, we would also like to express our sincerest gratitude to the members of the editorial board and the staffs of the editorial department for their efforts in editing manuscripts, processing articles, and promoting our journal to potential authors and readers. We firmly believe that TBCR will foster the growth of breast cancer research and facilitate its further development in China and the rest of the world.

\section{Acknowledgments}

Funding: None.

\section{Footnote}

Provenance and Peer Review: This article was commissioned by the editorial office, Translational Breast Cancer Research. The article did not undergo external peer review.

Conflicts of Interest: The author has completed the ICMJE uniform disclosure form (available at http://dx.doi.org/10.21037/ tbcr.2020.03.02). Dr. JZ serves as an unpaid Editor-in-Chief of Translational Breast Cancer Research and has no other conflicts of interest to declare.

Ethical Statement: The authors are accountable for all aspects of the work in ensuring that questions related to the accuracy or integrity of any part of the work are appropriately investigated and resolved.

Open Access Statement: This is an Open Access article distributed in accordance with the Creative Commons AttributionNonCommercial-NoDerivs 4.0 International License (CC BY-NC-ND 4.0), which permits the non-commercial replication and distribution of the article with the strict proviso that no changes or edits are made and the original work is properly cited (including links to both the formal publication through the relevant DOI and the license). See: https://creativecommons.org/ licenses/by-nc-nd/4.0/. 
Page 2 of 2

Prof. Dr. Zefei Jiang Department of Breast Oncology, The Fifth Medical Center of Chinese PLA General Hospital, Beijing 100039, China.

(Email:jiangzefei@csco.org.cn)

Received: 27 February 2020; Accepted: 06 March 2020; Published: 10 April 2020.

doi: $10.21037 /$ tbcr.2020.03.02

View this article at: http://dx.doi.org/10.21037/tbcr.2020.03.02

doi: $10.21037 /$ tbcr.2020.03.02

Cite this article as: Jiang Z. Welcome to Translational Breast

Cancer Research. Transl Breast Cancer Res 2020;1:1. 